\title{
EVALUATION OF TREATMENT OF PARACOCCIDIOIDOMYCOSIS WITH COTRIMAZINE (COMBINATION OF SULFADIAZINE AND TRIMETOPRIM). PRELIMINARY REPORT
}

Benedito BARRAVIERA (1), Rinaldo Poncio MENDES (2), Jussara Marcondes MACHADO (3), Paulo Camara Marques PEREIRA (3). Maria Julia de SoUZA (4) \& Domingos Alves MEIRA ((5)

KEY WORDS: Paracoccidioidomycosis, cotrimazine, sulfadiazine and trimetoprim, cerebral paracoccidioidomycosis.

Treatment of paracoccidioidomycosis was started in 1940, when RIBEIRO ${ }^{11}$ first used sulfadiazine, a sulfamide derivative. Other derivati. ves were later tested and found to have an effect against the fungus. According to DEL NEGRO ${ }^{5}$, none of the sulfamide derivatives thus far used for the treatment of paracoccidioidomycosis has proved to be superior to sulfadiazine.

Even though today there are several alternative treatment programs, such as those involving amphotericin $\mathbf{B}^{5,8,10}$, ketoconazole ${ }^{9,10}$, or sulfonamides alone $\mathrm{e}^{1.5}$ or in combination with trimetoprim ${ }^{2.3 .7}$, some situations require special schedules. When cotrimazine, known by the commercial name TRIGLOBE $\mathrm{F}^{(\mathrm{R})}$ ( $820 \mathrm{mg}$ sulfa diazine and $180 \mathrm{mg}$ trimetoprim), was first mar keted in Brazil, it became possible to use this combination for the treatment of paracoccidioidomycosis, since potentiation of the fungistatic effects occurs ${ }^{4}$ when these drugs are used in com bination. The authors ${ }^{3}$ tested the efficacy of the drug using 1 tablet of cotrimazine every 12 hours for 6 months. The dose was reduced by half after 6 months and maintained up to the end of 12 months of treatment. After this, the patients were maintained with $500 \mathrm{mg}$ sulfadoxin administered orally twice a week ${ }^{10}$.

Twenty one adult male patients aged 34 to 64 years with a confirmed diagnosis of paracocci dioidomycosis were studied. The clinical form of the disease ${ }^{6}$ was the adult chronic type, with 8 unifocal cases ( 1 mild case and 7 moderate ca ses) and 13 multifocal cases ( 4 mild, 7 moderate and 2 severe cases). Therapeutic effectiveness was assessed on the basis of clinical evolution, serology (immunodiffusion on agar gel), radiology and mycology.

Of the 21 patients studied, $18(85.72 \%)$ sho wed improvement with clinical remission and

(1) Professor Assistente Doutor do Departamento de Moléstias Infecciosas e Parasitárias, Dermatologia e Radiologia da Facul dade de Medicina de Botucatu (UNESP), Botucatu, Sāo Paulo, Brasil.

(2) Professor Adjunto do Departamento de Moléstias Infecciosas e Parasitárias, Dermatologia e Radiologia da Faculdade de Medicina de Botucatu (UNESP), Botucatu, Sāo Paulo, Brasil

(3) Professor Assistente do Departamento de Molestias Infecciosas e Parasitarias, Dermatologia e Radiologia da Faculdade de Medicina de Botucatu (UNESP), Botucatu, Sāo Paulo, Brasil.

(4) Técnico do Laboratório de Moléstias Infecciosas e Parasitárias da Faculdade de Medicina de Botucatu (UNESP), Botucatu. São Paulo, Brasil.

(5) Professor Titular do Departamento de Moléstias Infecciosas e Parasitárias, Dermatologia e Radiologia da Faculdade de Medicina de Botucatu (UNESP), Botucatu, Sâo Paulo, Brasil.

Address for correspondence: Dr. Benedito Barraviera. Faculdade de Medicina de Botucatu, Universidade Estadual Paulista "Julio de Mesquita Filho"(UNESP). CEP 18610, Botucatu, SP, Brasil. 
BarRaviera, B.; MENDES, R. P.; MACHAdO, J. M.; PEREIRA, P. C. M.; SOUZA. J. M. de \& MEIRA. D. A. Evaluation of treatment of paracoccidioidomycosis with cotrimazine (combination of sulfadiazine and trimetoprim). Preliminary report. Rev. Inst. Med. trop. São Paulo, 31 (1): 53-55, 1989.

decreased serum antibody titers, and serology was negative in 3 of them 5,6 and 9 months after treatment was started. Of the 3 remaining patients, 2 abandoned treatment and 1 showed intolerance for the medication manifested as in creased transaminase levels, eosinophilia and sulfhemoglobin formation. An alternative treatment was instituted for this patient.

The 15 patients with positive serology are described below:

\begin{tabular}{rcccl}
\hline PATIENT & $\begin{array}{c}\text { INITIAL } \\
\text { SEROLOGY }\end{array}$ & $\begin{array}{c}\text { TIME OF } \\
\text { TREATMENT }\end{array}$ & $\begin{array}{c}\text { PRESENT } \\
\text { SEROLOGY }\end{array}$ & CLINICAL FORM \\
\hline 1 & $1 / 4$ & 18 months & + pure & unifocal moderate \\
2 & $1 / 128$ & 18 months & $1 / 4$ & multifocal severe \\
3 & $1 / 32$ & 18 months & $1 / 4$ & multifocal moderate \\
4 & $1 / 64$ & 16 months & $1 / 2$ & multifocal moderate \\
5 & $1 / 32$ & 14 months & $1 / 2$ & multifocal moderate \\
6 & $1 / 8$ & 13 months & + pure & unifocal moderate \\
7 & $1 / 32$ & 13 months & + pure & unifocal moderate \\
8 & $1 / 4$ & 11 months & + pure & multifocal mild \\
9 & $1 / 128$ & 10 months & $1 / 16$ & multifocal moderate \\
10 & $1 / 32$ & 10 months & $1 / 4$ & unifocal moderate \\
11 & $1 / 64$ & 9 months & $1 / 16$ & unifocal moderate \\
12 & $1 / 32$ & 9 months & $1 / 4$ & multifocal mild \\
13 & $1 / 16$ & 7 months & $1 / 16$ & multifocal severe \\
14 & $1 / 4$ & 6 months & $1 / 4$ & multifocal moderate \\
15 & $1 / 256$ & 6 months & $1 / 64$ & multifocal moderate \\
\hline
\end{tabular}

For the two patients with the multifocal severe form, one of whom had skin, oral mucosa and lung lesions (patient 2) and the other lung and central nervous, system lesions (patient 13), it was necessary to increase the dose. Since patient 2 showed worsening signs and symptoms after 1 month of treatment, treatment was in creased to 2 cotrimazine tablets every 12 hours. This new dosage was maintained for 30 days and improvement occurred, with remission of clinical manifestations and reduction in antibody titer. The dose was then reduced again to 1 tablet every 12 hours and maintained at this level for 12 months.

Patient 13 initially took 2 cotrimazine tablets every 12 hours in combination with $500 \mathrm{mg}$ sulfadiazine every 8 hours. This schedule was maintained for 21 days, after which cotrimazine was reduced to 1 tablet every 12 hours and sulfadiazine maintained at the same dosage. This schedule was maintained for 3 months and the patient is currently taking 1 TRIGLOBE $F^{\text {t }}$ ta blet orally every 12 hours, with obvious improve ment in clinical condition and in computerized axial tomography, as shown below. (Fig. 1, 2).

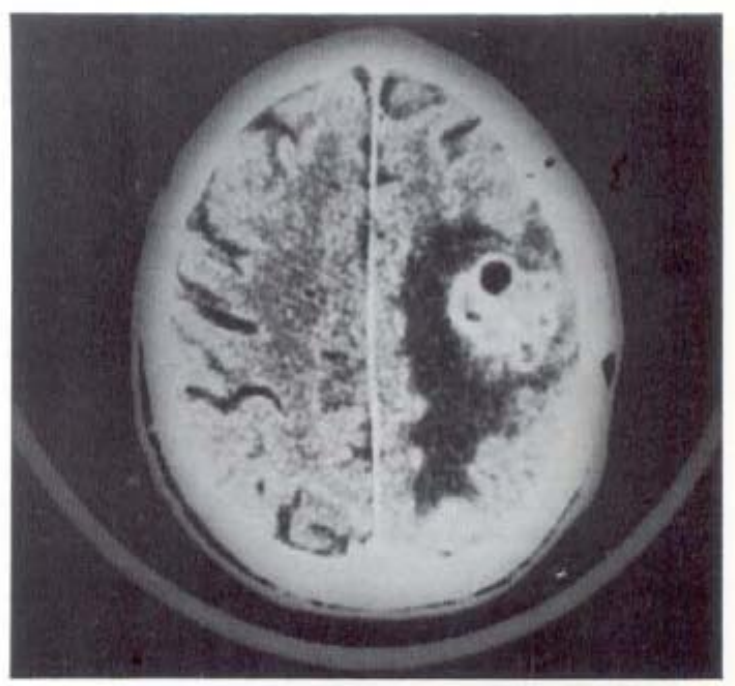

Fig. 1 - Computerized axial tomography of patient 13, before treatment. October 24,1987 - (with contrast).

Polycystic hyperdense mass with hyper-uptake, surrounded by a hypodense area with hypo-uptake.

Conclusion: Active multicystic inflammatory process. 
BARRAVIERA, B.; MENDES, R. P.; MACHADO, J. M.; PEREIRA, P. C. M.; SOUZA, J. M. de \& MEIRA, D. A. Evaluation of treatment of paracoccidioidomycosis with cotrimazine (combination of sulfadiazine and trimetoprim). Preliminary report. Rev. Inst. Med. trop. São Paulo, 31 (1): 53-55, 1989.

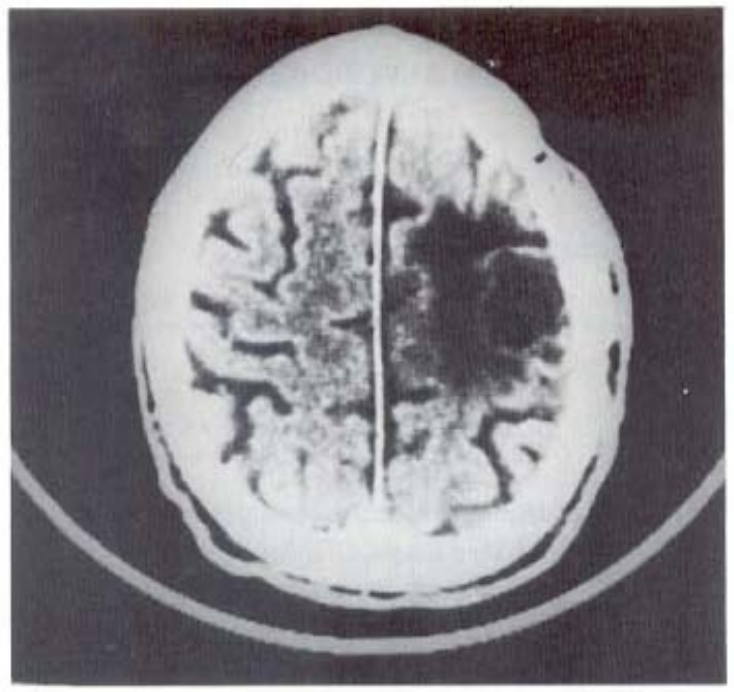

Fig. 2 - During treatment - April 5. 1988 - (with contrast). Polycystic hypodense mass with hypo-uptake, with a healing process.

Conclusion: Healing inflammatory process

On the basis of these preliminary results, the combination of sulfadiazine and trimetoprim proved to be useful for the treatment of paracoccidioidomycosis patients attended on an outpatient clinic basis. On the other hand, cotrimazine seems to be a good therapeutic alternative for patients with the cerebral form of paracoccidioi domycosis, since both sulfadiazine and trimeto. prim cross the cerebrospinal-blood brain barrier quite well.

\section{ACKNOWLEDGEMENTS}

We wish to thank MERREL-LEPETIT for providing us with TRIGLOBE F.

\section{REFERENCES}

1. BARBOSA, W. \& DAHER, R. R. - Blastomicose sul ameri cana (Paracoccidioidomicose). In: VERONESI, R. Doenças infecciosas e parasitárias. 7 . ed. Rio de $J$ aneiro, Guanabara Koogan, 1982, p. 638-651.
2. BARBOSA, W. \& VASCONCELLOS, W. M. de P. V. Açào da sulfametoxazol associada ao trimetoprim na tera pèutira da blastomicose sul americana. Rev. Pat. trop., 2: $329-339,1973$.

3. BARRAVIERA, B.: MENDES, R. P.; MACHADO, J. M. PEREIRA, P. C. M ; de SOUZA, M. J. \& MEIRA, D. A - Avaliaçāo do tratamento da paracoccidioidomicose pe la cotrimazina (associação sulfadiazina e trimetoprimı. In: CONGRESSO DA SOCIEDADE BRASILEIRA DE ME DICINA TROPICAL, 24, Manaus, 1988. Anais. Manaus, 1988. p. 44

4. BUDEL, A. R; FERNANDES, G. P: LAMEIRA, R. F. \& TELLES FILHO, F. Q. - Sensibilidade "in vitro" do Paracoccidioides brasiliensis à associaçāo trimetoprim sulfametoxazol. Rev. Soc. bras. Med. trop., 20 (supl. 1): 76,1987 .

5. DEL NEGRO, G. - Tratamento. Controle de cura. Profi laxia. In: DEL NEGRO, G.; LACAZ, C. S. \& FIORILLO, A. M. - Paracoccidioidomicose (blastomicose sul americana). Sảo Paulo, Sarvier; EDUSP, 1982. p. 271283.

6. FRANCO, M. F: MONTENEGRO, M. R.; MENDES, R P.; MARQUES, S. A.; DILLON, N. L. \& MOTA, N. G. S. - Paracoccidioidomycosis: a recently proposed classifi. cation of its clinical forms. Rev. Soc. bras. Med. trop., 20: $129 \cdot 132,1987$

7. GUERREIRO, C. A. M.; CHULUC, S. S. D. \& BRANCHI NI, M. L. N - A new treatment for large cerebral paracoc cidioidom ycosis. Arq. Neuro-psiquit. (S. Paulo), 45: 419-423, 1987.

8. MARCONDES, J.; BARRAVIERA, B.; MEIRA, D. A. \& MENDES, R. P. - Emprego da anfotericina $B$ corrigida pelo clearence de creatinina em doentes com Paracocci dioidomicose. In: CONGRESSO DA SOCIEDADE BRA SILEIRA DE MEDICINA TROPICAL, 18, Ribeirão Preto, 1982. Anais. Ribeiráo Preto, 1982. p. F'19

9. MARCONDES, J.; MEIRA, D. A.; MENDES, R. P .; PEREI RA, P. C. M.; BARRAVIERA. B.; MOTA, N. G. S. \& MOR CELLI, J. - Avaliaçāo do tratamento da Paracoccidioido. micose com o ketoconazol. Rev. Inst. Med. trop. S. Paulo, 26: $113-121,1984$.

10. MENDES, R. P. - Paracoccidioidomicose. In: MEIRA D. A. - Terapeutica de doenças infecciosas e parasitárias. Rio de Janeiro, EPUME, 1987. Cap. 28. p. 175-182.

11. RIBEIRO, D. O. - Nova terapéutica para a blastomicose Publ. méd. (S. Paulo), 12: 36-54, 1940.

Recebido para publicação em 9/6/1988 